\title{
Application of Motivation in Nigeria Construction Industry: Factor Analysis Approach
}

\author{
Afuye Funso $^{1}$, Letema Sammy ${ }^{1} \&$ Munala Gerryshom ${ }^{2}$ \\ ${ }^{1}$ Department of Environmental Planning and Management, Kenyatta University, Nairobi, Kenya \\ ${ }^{2}$ Centre for Urban Studies, Jomo Kenyatta University of Agriculture and Technology, Nairobi, Kenya \\ Correspondence: Afuye Funso, School of Environmental Studies, Kenyatta University, P. O. Box 43844-00100, \\ Nairobi, Kenya. E-mail: bldrafuye@ gmail.com
}

Received: January 13, 2016

Accepted: February 14, 2016

Online Published: April 25, 2016

doi:10.5539/ijef.v8n5p271

URL: http://dx.doi.org/10.5539/ijef.v8n5p271

\begin{abstract}
Motivation application by industry players is expedient for effective workforce towards meeting organisation goal. This study identified motivation variables in accordance with Herzberg theory. This was used to survey factors that influence supervisors' productivity as well as determining its application by contractors in Nigeria construction firms. Quantitative research design approach was employed with same questionnaire to supervisors and contractors. 174 questionnaires were administered to supervisors and 105 was filled and returned which constitute $60 \%$ success rate. Moreover, 16 questionnaires were administered to contractors and 12 was filled and returned which constitute $75 \%$ success rate. Analysis was done by descriptive statistics and Exploratory Factor Analysis (EFA). The outcome reveals that supervisors are mostly motivated by job security with mean score of 4.11 and standard deviation of .95 and least motivated by overtime with mean value of 2.82 and standard deviation of 1.14. Moreover, the most potent factor influencing their productivity is financial reward. However, the analysis of contractors' application of motivation reveals that they operate non financial reward. The paper recommends relating motivation application to workers needs as a way of enhancing productivity in the sector. Furthermore, enactment of employment protection legislations for job security should be enhanced to guide against arbitrary dismissal or retrenchment in the sector.
\end{abstract}

Keywords: contractors, motivation, motivation theory, Nigeria, productivity, supervisors

\section{Introduction}

Construction industry has been labelled unproductive across the nations of the world as a result of low productivity being recorded in the sector (Eldin \& Egger, 1990; Aiyetan \& Olotuah, 2006). Empirical studies have equally laid credence to this observation (Adnan et al., 2009; Adjei, 2009). This low performance has been attributed to lack of effective utilization of working hours per day by workers in the sector (Mendes \& Hewage, 2014). This issue of productivity decline was observed by the world Economic Forum in its 2011-2012 global competitiveness report. The report indicates that across the regions of the world, Africa has the second lowest productivity growth rate of -1.1 percent between 1987-1995 and 1.3 percent between 1995-2007.

Nigeria construction sector is not an exception. In West Africa sub-region, Umoru and Yaquib (2013) reported that productivity growth rate in Nigeria is 1.2percent between 2000-2008 below other countries in the sub-region and by far below the sub-regional average of 1.9 percent. GDP levels of sectors were compared in Nigeria, and the outcome indicates that in 2008; construction sector contributed 1.3percent and was ranked seventh out of twelve sectors considered in the report. In 2013, its contribution increased to 3.1 percent but its ranking dropped to ninth. The poor performance of this sector has been linked to inadequate motivation of workers. It is worthy of note that researchers have concentrated efforts on motivating factors that can enhance productivity improvement and came out with recommendations in this regard (Smither, 2000; Ng et al., 2004: Aiyetan \& Olotuah, 2006). However, the applicability of this recommendation by industry players is another issue yet to be considered.

\section{Objectives}

The paper has the following objectives:

1) To determine the influence of motivating factors on supervisors in Nigeria construction industry. 
2) To determine motivating factors as applied by contractors in the industry and establish whether it is in line with workers needs.

\section{Theoretical Framework}

Motivation has been defined severally by various authors (Jean et al., 2006; Cox et al., in Barg et al., 2014). However, the summary of these definitions is that it is an incentive, catalyst, or driving force that directs the behaviour of individual towards achieving a set of objectives with a view to meeting personal need and achieve organisational goal. Motivation theory has been evolving, beginning from hedonistic perspective that sees man as lovers of pleasure and haters of pain to contemporary concept of motivation. This contemporary concept is grouped into content and process theories (Aiyetan \& Olotuah, 2006; Steers et al., 2014). This framework will focus on content theory from which the study concept was derived.

The main aim of content theory is to shift focus from organisational goal and group motivation to individual motivation (Stone \& Patterson, 2005). The major contributors to this theory are Maslow, Herzberg and McClelland. Maslow' hierarchy of needs theory focused on the identification of factors responsible for motivation of individuals (Steer et al., 2004). The view of Maslow (1943) is that man desires to grow from one level to the other along a pyramid. The growth need of man follows this order: physiological, security, love, esteem and self actualisation (Maslow, 1943). He argued that the first three needs are deficiency needs that one must overcome to be an ideal personality; while the last two are growth needs that are not activated as a result of deficiency.

He concluded that man behaviour is directed towards the actualisation of these needs. Hence, serves as a source of motivation of individual. The critics of this theory believed it was not based on empirical data and cannot be scientifically proof (Nzibo, 1988). However, from the perspective of this study, Maslow' theory is a pointer to the path that any purpose driven man should take to be an accomplished personality.

Furthermore, Herzberg observed that if the deficiency needs in Maslow' hierarchy are met, it doesn't guarantee productivity increase except if the growth needs are met also (Stone \& Patterson, 2005). Therefore, Herzberg re-directed his theory towards workers needs in such a way that productivity attainment will be achieved, this makes Herzberg begun the evolution of intrinsic and extrinsic motivating factors to further improve on Maslow' theory. Herzberg made some assumptions that there should be separation between what causes dissatisfaction in workplace and what motivates worker (Jean et al., 2006). Herzberg (1968) identified negative and positive 'KITA' (Kick in the pant). This is an application of some measures to get things done. Negative 'KITA' according to him is an uncomplimentary way of getting work done; this might be in form of shouting at worker, monitoring his activities and even kicking the person.

However, he identified positive 'KITA' as a better option. This involves the use of incentives such as more status, promotion, reward and bonus to get people to work towards the attainment of organisational goals. He argued that these incentives only forced the recipients to move, and that the movement is not from his heart. For the movement to come from his heart; there are other factors that can make this possible. These include reduction in working hour, increase or decrease in salary depending on economy, extra benefits, training, communication, job participation and involvement of counsellors. He argued further that in a work setting, growth is desired and this is contained in work content. This includes achievement, appreciation, satisfaction derived from job, responsibility and advancement.

He also identified factors that could help in the avoidance of dissatisfaction he referred to as hygiene factors. This also includes company policy and administration, good supervision, interpersonal affiliation, good working condition, rank, salary and security. He concluded that motivation produce job satisfaction while hygiene factors produce job dissatisfaction. In this study, the motivation factors used is based on Herzberg motivating factors as a result of its popularity among researchers.

\section{Study Methodology}

The study area for this survey is Lagos, Nigeria. Quantitative design approach was used. This includes review of literature that assisted in getting variables that were used for the study. Sixteen variables were identified and used for this study. The study population is the site supervisors and contractors represented by the companies surveyed. Large and medium sized companies only were included in the survey on the assumption that they will have stable organisational structures that will be good for this type of study. Sixteen companies were surveyed as against twenty got by simple random sampling. The remaining companies denied the research team permission to their sites.

Purposive sampling technique was used to administer questionnaire to 174 supervisors through personal contact 
in all the sites surveyed. However, 105 was filled and returned. This constitute $60 \%$ success rate achieved. The respondents were asked to rank motivating factors on Likert scale of 1-5 according to the level of influence it has on them. The contractors on the other hand were asked to rank the factors in accordance with how it is applied in their various firms. This assisted in comparing its application with workers need. The method used for the analysis is both descriptive and explorative factor analysis (EFA). This was used in grouping the factors according to potency to confirm results of descriptive analysis. However, because of the small sample of contractors involved in the survey EFA could not be used to group their views. Thereafter, comparison was made between the two groups. Yong and Pearce (2013) opined that EFA helps to make meaning out of variables by categorising them into clusters based on their effects.

\section{Results of Data Analysis}

The output of the ranking of site supervisors' responses to motivating factors influence on their productivity is presented in Table 1. Job security is the most influential factor on supervisors' productivity with mean score of 4.11 and SD value of .95 . The second most ranked factor is good salary with mean value of 3.95 and SD value of .70. The third influential factor is compliance with safety provision with mean value of 3.94 and SD value of .62. However, it can be noted that beside the third most ranked factor, the first six factors are directly connected with financial reward. It is therefore not out of place to conclude that supervisors in Nigeria construction firms are motivated mostly by financial reward. The least motivator is working overtime. The study went further to explore the pattern of relationship between these variables using exploratory factor analysis (EFA) to see whether it conforms to the one established by ranking.

Table 1. Ranking of influence of motivating factors on supervisors' productivity

\begin{tabular}{cccc}
\hline Factors & Mean & Standard Deviation & Rank \\
\hline Job security & 4.11 & .95 & 1 \\
Good salary & 3.95 & .70 & 2 \\
Compliance with safety & 3.94 & .62 & 3 \\
Appreciation of effort & 3.91 & .58 & 4 \\
Bonus & 3.87 & .67 & 5 \\
Promotion opportunity & 3.73 & .69 & 6 \\
Skill development & 3.63 & .72 & 8 \\
Challenging work & 3.39 & .69 & 9 \\
Good supervision & 3.33 & .62 & 10 \\
Recognition by authority & 3.32 & .71 & 11 \\
Cooperation from others & 3.30 & .65 & 12 \\
Good work environment & 3.28 & .63 & 13 \\
Satisfaction from work & 3.20 & .83 & 14 \\
Taking part in decision & 3.16 & .82 & 15 \\
Freedom at work & 2.87 & .68 & 16 \\
Working overtime & 2.82 & & \\
\hline
\end{tabular}

Source: Authors field survey, 2015.

Sixteen items of motivation factors were subjected to exploratory factor analysis (EFA) on SPSS version 17. Suitability of data for EFA was assessed by the use of Kaiser Meyer- Oklin' (KMO) and Barlett' test of sphericity indicated in Table 2. KMO value was .697, this exceeds the value of .5 recommended and Barlett's test of sphericity $\mathrm{X}^{2}(120)=478.307$ at $\mathrm{P}<.001$ which is significant. This is an indication of patterned relationship between the items and a reflection of factorability of the correlation matrix.

Table 2. SPSS output for KMO and Barlett's test

\begin{tabular}{ccc}
\hline \multicolumn{2}{c}{ Kaiser-Meyer Olkin Measure of Sampling Adequacy } & .697 \\
Barlett Test of Sphericity & Approx. Chi-Square & 478.07 \\
& & \\
& Df & 120 \\
& Sig. & .000 \\
\hline
\end{tabular}

Table 3 is the output of total variance explained of individual variables in the factor. It assisted to know the number of factors to extract. Factor extraction is done based on variables that have greater influence on the 
factors being considered.

The ones that have weak variance are eliminated. This assists in using variables with greater influences to determine the outcome of the analysis. The factors with eigenvalues greater than 1 were extracted. This gave six factors with eigenvalues greater than 1 and explained a total variance of $50.36 \%$ as reflected in bold letter.

Table 3. Output for total variance explained

\begin{tabular}{|c|c|c|c|c|c|c|c|c|c|}
\hline \multirow[b]{2}{*}{ Factor } & \multicolumn{2}{|c|}{ Initial Eigenvalues } & \multirow[b]{2}{*}{ Cum. \% } & \multicolumn{3}{|c|}{ Extraction sums of squared loadings } & \multicolumn{3}{|c|}{ Rotation sums of squared loadings } \\
\hline & Total & $\%$ of Variance & & Total & $\%$ of Variance & Cum. $\%$ & Total & $\%$ of Variance & Cum. $\%$ \\
\hline 1 & 4.08 & 25.47 & 25.47 & 3.62 & 22.59 & 22.59 & 2.09 & 13.04 & 13.04 \\
\hline 2 & 2.14 & 13.40 & 38.87 & 1.70 & 10.63 & 33.22 & 1.51 & 9.43 & 22.47 \\
\hline 3 & 1.46 & 9.14 & 48.01 & .90 & 5.61 & 38.82 & 1.41 & 8.78 & 31.26 \\
\hline 4 & 1.18 & 7.35 & 55.36 & .69 & 4.30 & 43.13 & 1.20 & 7.50 & 38.75 \\
\hline 5 & 1.12 & 6.97 & 62.33 & .61 & 3.80 & 46.93 & 1.10 & 6.88 & 45.63 \\
\hline 6 & 1.03 & 6.45 & 68.78 & .55 & 3.44 & 50.36 & .76 & 4.73 & 50.36 \\
\hline 7 & .82 & 5.12 & 73.90 & & & & & & \\
\hline 8 & .74 & 4.61 & 78.51 & & & & & & \\
\hline 9 & .68 & 4.28 & 82.79 & & & & & & \\
\hline 10 & .57 & 3.56 & 86.35 & & & & & & \\
\hline 11 & .51 & 3.22 & 89.56 & & & & & & \\
\hline 12 & .45 & 2.81 & 92.37 & & & & & & \\
\hline 13 & .39 & 2.44 & 94.80 & & & & & & \\
\hline 14 & .31 & 1.95 & 96.75 & & & & & & \\
\hline 15 & .30 & 1.88 & 98.63 & & & & & & \\
\hline 16 & .22 & 1.37 & 100.0 & & & & & & \\
\hline
\end{tabular}

Extraction Method: Principal Axis Factoring.

Rotation was done by the use of orthogonal varimax. After rotation the factors were arranged in order of potency based on the most explained variance as presented in Table 4. Items in factor 1are good salary, bonus, promotion opportunity, appreciation of efforts and job security are all related to financial reward. They are the most dominant factors influencing supervisors' performance. This conforms to the ranking in Table 1.

Table 4. Rotated factor matrix

\begin{tabular}{|c|c|c|c|c|c|c|}
\hline & \multicolumn{6}{|c|}{ Factor } \\
\hline & 1 & 2 & 3 & 4 & 5 & 6 \\
\hline Good salary & & & & & & \\
\hline Bonus & & & & & & \\
\hline Promotion opportunity & .630 & .431 & & & & \\
\hline Appreciation of effort & & & .348 & .399 & & \\
\hline Job security & & & & & & \\
\hline Satisfaction from work & & & & & & \\
\hline Cooperation from others & & & & & & \\
\hline Freedom at work & & & & & & \\
\hline Good supervision & & & & & & \\
\hline Good work environment & & & & & & \\
\hline Taking part in decision & & & & & & \\
\hline Recognition by authority & & & & & & \\
\hline Challenging work & & & & & & \\
\hline Compliance with safety & & & & & & \\
\hline Skill development & & & & & .385 & .453 \\
\hline Working overtime & & & & & & \\
\hline
\end{tabular}

The second most dominant factor according to Table 4 is satisfaction from work, cooperation from workers and freedom at work. This factor can be termed social relations factor, which is the desire to associate and relate with others. The third group consists of good supervision and good work environment. This factor can be called work 
environment factor. The forth factor contains taking part in decision and recognition by authority. This factor is referred to as social status factor by this study and is related to the desire of man to be esteemed by others in accordance with Maslow' theory. The fifth factor contains challenging work and compliance with safety. This is referred to as safety need of workers because challenging work can as well be risky. The sixth factor contains opportunity for skill development and overtime. Working overtime increases the on the job hour and is expected to increase skill development. This is therefore called skill development need of workers. The study sought the views of contractors on motivation factors application in their firms. The result is presented in Table 5.

Table 5. Application of motivating factors by contractors

\begin{tabular}{cccc}
\hline Factors & Mean & Standard Deviation & Rank \\
\hline Challenging work & 4.08 & .69 & 1 \\
Skill development & 3.92 & .67 & 2 \\
Good supervision & 3.92 & .52 & 2 \\
Good work environment & 3.83 & .72 & 4 \\
Compliance with safety & 3.83 & .72 & 4 \\
Recognition by authority & 3.75 & .45 & 6 \\
Taking part in decision & 3.67 & .49 & 7 \\
Satisfaction from work & 3.42 & .79 & 9 \\
Freedom in workplace & 3.33 & 1.30 & 9 \\
Bonus & 3.33 & .98 & 11 \\
Good salary & 3.25 & .62 & 12 \\
Appreciation of efforts & 3.17 & 1.03 & 13 \\
Cooperation from others & 3.08 & .79 & 13 \\
Job security & 3.08 & .67 & 15 \\
Opportunity to be promoted & 3.00 & .74 & 1.00 \\
\hline
\end{tabular}

The most used motivator is challenging work with mean score of 4.08 and SD of .69, closely followed by opportunity for skill development with mean value of 3.92 and SD of .67. It will be appropriate to say that these two go together. Challenging work enhances skill development. The complexity of projects being executed by these companies can be challenging, at the end of the day improve the skill of workers. The next that shares this second position is good supervision with mean score of 3.92 and SD of .55. Good work environment and Compliance with safety provision are the forth on the list with mean score of 3.83 and SD of .72 respectively.

The least applied motivator is working overtime with mean score of 2.50 and $\mathrm{SD}$ of 1.00 . This equally reflects the mood of workers. It should however be noted that the first nine most ranked factor by contractors are non financial reward. This is an indication that Nigeria construction firms do not relate motivation with workers need. Supervisors prefer financial reward, while contractors operate non financial.

\section{Discussions of Results}

Job security is the most ranked motivating factor by supervisors. This might likely be as a result of increase in unemployment rate in Nigeria and unpredictability of construction climate with attendant seasons of boom and depression. The dominant motivating factor is financial reward as reflected in the patterned relationship established in Table 4. This constitute factor 1. The implication of this result is that for effective performance of supervisors to be ensured, monetary reward should be used as a way of enlisting their cooperation towards greater productivity. This result is in line with Aiyetan and Olotuah (2006) that Nigeria construction workers are motivated by financial reward. Similar study in Iran by Ghoddousi (2014); Ogunlana and Chang (1998) in Thailand gave the same result. However, Ogunlana and Chang (1998) linked this result to the economy of these nations. The analysis of the application of motivating factors by contractors indicates that they prefer non financial reward. Therefore, application of motivator is not in relation with workers need. Supervisors prefer financial reward while contractors operate non financial. For productivity increase to be attained, contractors should relate reward system to the need of workers. Application of financial reward will be a booster to the attainment of organisational goal, thereby boosting GDP of construction sector.

Job security of construction workers in Nigeria should be ensured. This can be achieved by enactment of employment protection legislation. This law will protect workers against illogical dismissal and retrenchment. 


\section{Conclusion}

Study on motivating factors influence on supervisors and its application in Nigeria construction industry was conducted. The outcome indicates that supervisors are mostly motivated by financial reward. This includes good salary, bonus, promotion opportunity, appreciation of efforts and job security. However, the ranking of motivating factors as applied by contractors do not reflect the need of workers. Contractors prefer non financial incentives. The basis of motivating workers is to relate reward to need; this is contrary in Nigeria construction industry.

\section{References}

Adjei, E. A. (2009). Motivational Strategies to Improve Productivity in the Construction Industries in Ghana. An unpublished M.Sc Thesis of the Department of Building Technology, Kwame Nkrumah University of Science and Technology, Kumasi, Ghana.

Adnan, E., Sherif, M., \& Saleh, A. (2009). Factors Affecting the Performance of Construction Projects in the Gaza Strip. Journal of Civil Engineering and Management, 15(3), 269-280. http://dx.doi.org/10.3846/1392-3730.2009.15.269-280

Ayeitan, A. O., \& Olotuah, A. O. (2006). Impact of Motivation on Workers Productivity in the Nigerian Construction Industry. Proceedings $22^{\text {nd }}$ ARCOM Conference $4-6^{\text {th }}$ September, 2006. Birmingham, U.K. Association of Research in Construction Management, pp. 239-248.

Barg, J. E., Ruparathna, R., Mendis, D., \& Hewage, K. N. (2014). Motivating Workers in Construction. Journal of Construction Engineering, July, 2014. http://dx.doi.org/10.1155/2014/703084

Ghoddousi, P., Bahrami, N., Chileshe, N., \& Hosseni, M. R. (2014). Mapping Site- Based Construction Worker's Motivation: Expectancy Theory Approach. Australasian Journal of Construction Economics and Building, 14(1), 60-67. http://dx.doi.org/10.5130/ajceb.v14i1.3712

Jean, H. M., John, B., \& Carolyn, F. (2006). Organisational Behaviour in a Global Context. London, Prentice Hall.

Maslow, A. H. (1943). A Theory of Human Motivation. Psychology Review, 50, 370-396. http://dx.doi.org/10.1037/h0054346

Ng, S. T., Skitmore, R. M., Lam, K. C., \& Poon, A. W. C. (2004). Demotivation Factors Influencing the Productivity of Civil Engineering Projects. International Journal of Project Management, 139-146. http://dx.doi.org/10.1016/S0263-7863(03)00061-9

Nzibo, Y. A. (1988). The Evolution of the Various Theories on the Subject of Motivation. The Paper Presented to the MBA Class, Lansdowne Independent College, London, June.

Ogunlana, S. O., \& Chang, W. P. (1998). Worker Motivation on Selected Construction Sites in Bangkok, Thailand. Engineering Construction and Architectural Management, 5(1), 68-81. http://dx.doi.org/10.1046/j.1365-232X.1998.00008.x

Smithers, G. L., \& Walker, D. H. T. (2000). The Effect of the Workplace on Motivation and De-motivation of Construction Professionals. Construction Management and Economics, 18, 833-841. http://dx.doi.org/10.1080/014461900433113

Steers, R. M., Mowday, R. T., \& Shapiro, D. L. (2004). Introduction to Special Topic Forum: The Future of Work Motivation Theory. Academy of Management Review, 29(3), 379-387. http://dx.doi.org/10.2307/20159049

Stone, A. G., \& Patterson, K. (2005). The History of Leadership Focus. Servant Leadership Research Roundtable- August.

Umaru, D., \& Yaquib, J. O. (2013). Labour Productivity and Health Capital in Nigeria. The Empirical Evidence. International Journal of Humanities and Social Sciences, 3(4).

\section{Copyrights}

Copyright for this article is retained by the author(s), with first publication rights granted to the journal.

This is an open-access article distributed under the terms and conditions of the Creative Commons Attribution license (http://creativecommons.org/licenses/by/3.0/). 